Onysenko T. S., PhD in Economics Mykytiuk O. P., PhD in Economics Magomedova A. M., PhD in Economics Taras Shevchenko National University of Kyiv Kyiv, Ukraine

DOI: https://doi.org/10.30525/978-9934-26-028-5-27

\title{
DIGITAL POTENTIAL OF UKRAINIAN COMPANIES
}

The development of the global economy in 2020 was marked by the uncertainty of strategies and because of the global Covid-19 pandemic, planning processes became much more complicated. This in turn affected the economic activity of enterprises of Ukraine and the world. Most business structures have been forced to use new business technologies and reorient their activities to an online format.

In the context of global digitalization of economic processes, enterprises are faced with the urgent need to introduce new models for assessing their capabilities for the use of advanced information and communication technologies, which in turn take into account 
uninterrupted access to information technologies, and application skills, network communication capabilities own structural units. In this regard, the process of realizing the digital potential of Ukrainian enterprises becomes especially necessary.

The importance of studying the problems of realization of the digital potential of enterprises lies in the urgent need to develop applied tools for assessing the effectiveness of information technology in the activities of individual companies.

In the context of this study, it is worth mentioning Klaus Schwab's statement that the digital economy is characterized as an innovative and dynamic system based on the active introduction of innovations and information and communication technologies in all economic activities and spheres of society, increasing efficiency, and competitiveness of individual enterprises, the economy in general and living standards. The digital economy is the basis of the Fourth Industrial Revolution and the third wave of globalization [3]. The use of the digital potential of Ukrainian companies is a logical continuation of the international trend towards the active use of digital technologies and a significant increase in their impact on all spheres of both economic and social life in 2020.

However, first, it is necessary to define the category "digital potential of the company" To date, most scientific papers identify the concepts of digital and innovation potential. However, in our opinion, these concepts are related, but not identical. Thus, the innovative potential of the enterprise is defined as a set of capabilities of the enterprise to implement qualitatively new changes caused by the use of new technologies in its activities. Digital potential, in turn, is a possible set of information resources, information interaction systems of various uses that will increase the level of adaptation of the enterprise to rapidly changing environmental conditions.

Based on this definition, we can outline three fundamental components of the digital potential of the modern enterprise:

1) systematic interaction with environmental factors, which in practice is implemented by methods of analysis of information 
products, which will guarantee the use of relevant information in the further activities of the enterprise;

2) the ability and skills of employees of the enterprise to form relevant requests to the external environment and the use of information, information resources, their technical, organizational, and financial support;

3) an integration element that comprehensively combines the capabilities of the internal environment with the challenges of the external environment and gives synergistic effects in the process of realizing the digital potential of the enterprise.

Thus, the realization of the digital potential of modern Ukrainian enterprises will lead to their rapid adaptation to the challenges posed by the global Covid-19 pandemic, and as a result, led to a change in established economic norms.

After all, the World Bank Group notes the impact of digital technologies on GDP growth in the EU until 2025, that the penetration of fixed broadband Internet access adds $+1.7 \%$ to GDP, increased international capacity $(+0.66 \%$ to GDP), and the spread of e-commerce (+ $0.88 \%$ to GDP) [2]. This, in turn, allows us to talk about the need to realize the digital potential of Ukrainian companies.

Thus, the main features of the process of realization of digital potential include the following:

1. Technologies can develop faster than the ability of Ukrainian enterprises to respond to them.

2. Most companies with significant financial potential have the opportunity to realize their digital potential.

3. The process of realizing the digital potential of the enterprise must be constant, which is caused by the continuity of development of the world economic system.

Thus, given the definition and features of the process of realizing the digital potential of Ukrainian enterprises, we can conclude that in conditions of uncertainty caused by the global pandemic and given the constant change in external conditions of digitalization and intellectualization of economic activity becomes necessary in building sustainable economic relations. 
Thus, according to investment bank analysts, as of the beginning of 2018, only 4\% of industries underwent Disruptive innovations, 50\% under the influence of breakthrough technologies changed their business, business models and became organizations of a fundamentally new type; $96 \%$ of industries have yet to do so [1]. During the crisis of 2020, only those enterprises that actively used, increased, and multiplied their digital potential were able to adapt and achieve economic growth.

\section{References:}

1. Digital Spillover. Measuring the true impact of the digital economy. Huawei Technologies. URL: https://www.huawei.com/minisite/gci/en/digital-spillover/files/ gci_digital_spillover.pdf.

2. Digital Agenda of the Eurasian Economic Union until 2025: prospects and recommendations. World Bank Group. URL: http://documents.worldbank.org/ curated/pt/413921522436739705/pdf/EAEU-OverviewFull-RUS-Final.pdf

3. Schwab K. The fourth industrial revolution: translated from English. Moscow: Publishing House "E". 2017. P. 208 p. 